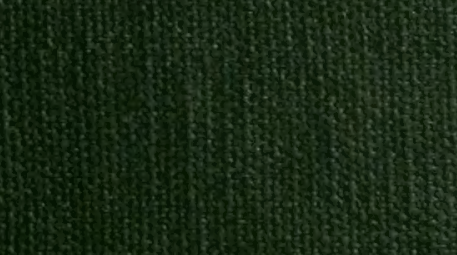

s.

$4 x^{2}+1$

$\begin{array}{lll}0 & \\ 1\end{array}$

5. 


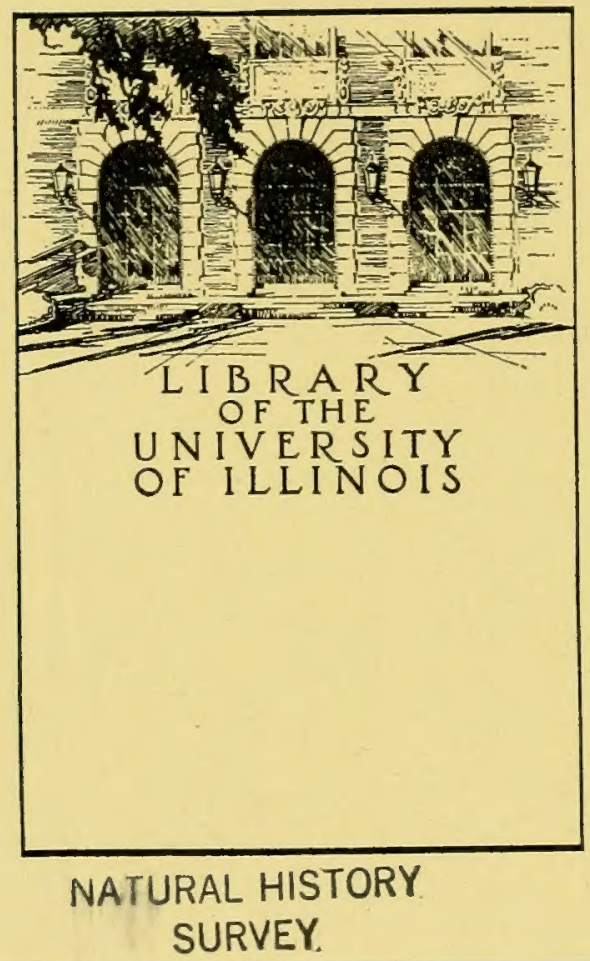








$$
\begin{gathered}
\text { State of Illinois } \\
\text { Henry Horner, Governor } \\
\text { Department of Registration and Education } \\
\text { John J. Hallihan, Director }
\end{gathered}
$$

THE WATERFOWI RESEARCH PROGRAN IN ILLINOIS

Arthur S. Hawkins

Frank C. Belirose, Jr.

Harry $G$. Anders on

Published by Authority of the state of Illinois

NATURAL HISTORY SURVEY

Theodore H. Frison, Chief

Biological Notes No. 12 Urbana, Illinois October, 1939 

Arthur S. Hawkins, Frank C. Bellrose, Jr., and Harry G. Anderson*

Through Illinois passes one of the heaviest flights of waterfowl found in inland North America. Capitalizing on this fact, thousands of hunters each fall spend many enjoyable hours at the 500 or more duch hunting clubs and at the public shooting areas within the state. The outlay of cash spent in pursuit of the sport of duck hunting runs into a million or more dollars each year.

Within the past decade a shortage of ducks and alterations in their environment have endangered the sport of hunting in Illinois and elsewhere. Regulations governing the take of waterfowl were necessarily tightened to conserve the fast diminishing breeding stock. These restrictions paid dividends; ducks are again increasing in number.

In accord with a nation-wide effort to prevent the reoccurrence of the noar-calamity to ducks and to the sport of duck hunting, the IJIinois Natural History Survey in Fobruary, 1938, undertook a waterfowl survey, in an effort to assomble facts pertinent to the management of the waterfowl resource in Illinois. This report outIines the progress of the survey, which to this timc has included principally the valley of the Ilinois River, referred to in this report as the Illinois Valley.

\section{ACTIVITIES AND FINDINGS}

The 1938 program included experimental plantings of aquatic vegetation, wood duck nesting studies, cover mapping and a survey of the duck hunting season.

\section{Experimental Plantings}

A dozen kinds of aquatic plants, rare or absent from the Ilinois Valley but highly rated as duck foods elsewhere, were tried in experimental plots. The rosult was similar to that obtained by many hunting clubs where these plants have becn tried in the past-. an unfavorable vater level killed the plants.

Wood Duck Studies

Preliminary information was gathered on the nesting of the wood duck, tho only duck which nests abundantly in Illinois. Further nesting studies were pursuod in 1939; a progress report covering both years is in preparation.

*Arthur S. Hawkins, Gamo Technician, Frank C. Bellrose, Jr., Assistant Game Technician, Illinois Natural History Survey; Harry G. Andorson, Junior Biologist, Illinois Natural History Survey, State Dopartmont of Conservation and U. S. Biological Survey, cooperating. 


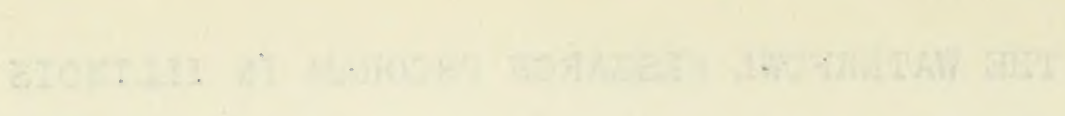


Hunters' mistakes in 1938 accounted for the illegal killing of hundreds of wood ducks. The wood duck is "beautiful but dumb" and falls an easy victim to the aim of novices who are unable to identify one species irom another. All increases in wood ducles resulting from improvement in the nestine habitat in 1938 are belieted to have been canceled by careless hunters.

Mechanically harvested grain fields were found to be an important source of food. Thp to 8,000 wood duclss have been observed in a sincle tvenine feeding in the crainfields in one drainage district near Ilavana.

\section{Ducl Food Survey in the IJIinois Valley}

The vegetation in all the important bottom-land lakes was mapped to scalo, to detcrmine the rolative abundance of various food and non-food plants. These maps will serve as a basis for comparison with conditions in future years. A comparison between the 1938 and 1939 findings is given later in this report.

Survey of the 1938 Hunting Season

A preliminary report of the survey of the 1938 duck hunting season in the Illinois Valley was presented before the Fourth North Amorican Vildife Conference, * held in Detroit in February, 1939. ruch aditional information is now avaliable, largely trurough the cooperation of the state Departmont of conservation in givine free access to reports from duck clubs. A revision of parts of the preliminary report, which was based on less information than is now available, is presented in the following summary.

1. Estimated total kill, including cripples lost: 85,000.

2. The kill by species of 250 clubs is given in tablo 1 .

Tablo 1.--Duck kill of 250 clubs, Illinois Valloy, 1938.

\begin{tabular}{|c|c|c|c|}
\hline DabbIing Ducks & Fumber & Diving Ducks & Tumbor \\
\hline $\begin{array}{l}\text { Mallard } \\
\text { Pintail } \\
\text { Green-winged teal } \\
\text { Gadwall } \\
\text { Baldpate } \\
\text { Bluo-winged teal } \\
\text { Shoveler } \\
\text { Blacl duck }\end{array}$ & $\begin{array}{r}32,047 \\
7,570 \\
5,652 \\
3,082 \\
2,568 \\
2,025 \\
1,437 \\
881 \\
\end{array}$ & $\begin{array}{l}\text { Lesser scaup (bluebill) } \\
\text { Ring-necled (blackjack) } \\
\text { Canvasback } \\
\text { Redhead } \\
\text { Bufflehead } \\
\text { Ruddy } \\
\text { Golden-eye } \\
\text { Miscollancous }\end{array}$ & $\begin{array}{r}537 \\
414 \\
240 \\
130 \\
129\end{array}$ \\
\hline tal & 55,262 & Total & \\
\hline
\end{tabular}

*This report was published in the July-August issue of Amorican Wildife. Reprints can be obtained by vriting to the Illinois Natural History Survoy, Urbana, IIlinois. 


3. Crippling losses (based on 1,009 man-day reports): 1,819 cripples were lost while 4,960 ducks were bejing bagged, an average of 3.7 cripples per limit of 10 duclis. This average includes both divine and dabbling ducks. About five divers vere lost per limit, as compared to half that many dabblers.

4. The 1938 fjocht: The flight of 1.938 was heavier and later than that of 1937 , accordine to reports. Vie estimate that at least 3 million duclss passed through the Illinois Valley in 1938. Nearly a half miliion ducks were seen at one time during tre peak of the flight on the Chantauqua Iake I"igratory Waterfowl Pefugo, near Havana. The average number of duclis per acre of Illinois Fiver bottom-land lake during the iall flight was about 45 . Somewiere in the neighbornood of 1 out of 40 ducles winch entered tho valley is believed to havo boen eliminated by hunters.

5. The 1938 flight by spocies: The ratio (per cent) of mallards to all other species combined, prosent at various poriods during the fall is given in table 2 .

Valley, 1938.

Tablo 2.--Ratio of mallards to all other ducks, IIIinois

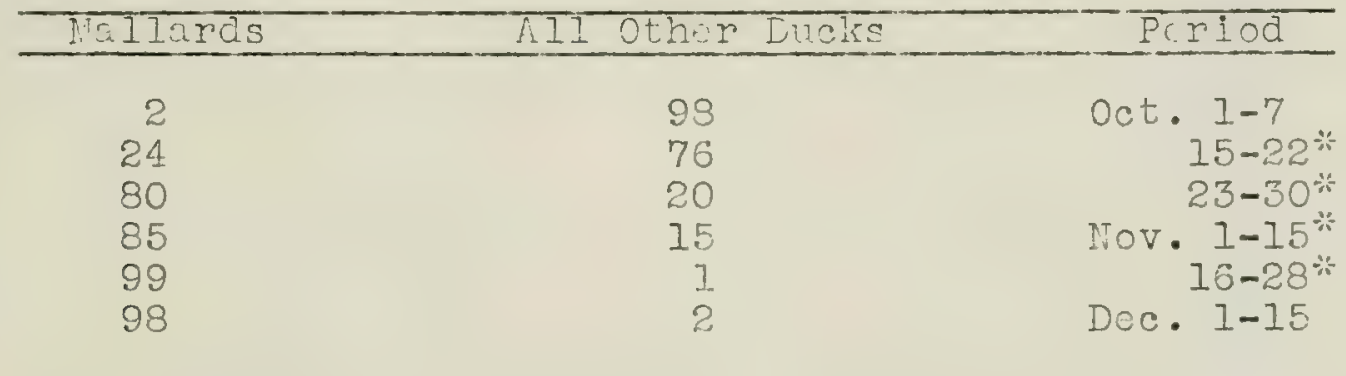

*1938 huntine soason (45 days)

The rolation of the peak and magnitude of the flight, in various specios, to tho dates of the 1938 hunting soason is represontod by the diagram on the proceding page.

6. Ki11 por hunter per day: Porhaps the best comparison of hunting conditions at various clubs and in various parts of the state is the avorage number of ducks bageed por hunter per day's shoot. On this basis the highest possible score within the law is 10 ducks per hunter por day; the lowest score is of course 0 .

The duck kill in the counties along the Illinois River is shown in table 3 . For some countios tho figuros aro more ncarly accurate than for others because thoy are based on largor samples. 

Table 3.-- Total bag and average man-day kill by clubs in the counties bordering the Illinois Fiver, 1938.

\begin{tabular}{|c|c|c|c|c|c|c|}
\hline County & $\begin{array}{l}\text { Club } \\
\text { Reports } \\
\text { Received }\end{array}$ & $\begin{array}{l}\text { Feport- } \\
\text { ed } \\
\text { rilled }\end{array}$ & $\begin{array}{l}\text { Clubs } \\
\text { Reporting } \\
\text { Wan-Days" }\end{array}$ & $\begin{array}{l}\text { Man-Days } \\
\text { Peported }\end{array}$ & $\begin{array}{l}\text { Ducks in } \\
\text { Man-Day } \\
\text { Reports }\end{array}$ & $\begin{array}{l}\text { iveraee } \\
\text { Man-Day } \\
\text { IIII }\end{array}$ \\
\hline
\end{tabular}

\section{Upper Fiver}

Grundy

La Salle

Bureau

Putnam

Marshall

Peoria

Woodford

Middle River

Tazewell

Fulton

6

835

13

8,468

$45 \quad 11,192$

1,893

4,800

33

1,154

Nias on

Schuyler

Cass

9
5

12

14

10

24

8

5

317

108

183

394

999

419

778

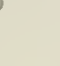

3

10

31

6

19
108

789

792

179

321

\section{Lower River}

Brown

lorgan

1

49 I

1, 749

958

648

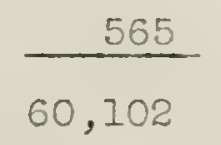

$s \cot t$

Pike

Jersey

Calhoun

Total

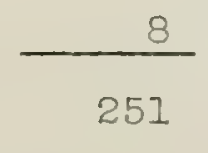

121

I$$
60,102
$$

718

1,822

5,803

1,974

3,892

1,905

262

$2 \cdot 42$
9

2

6

1

13

305

148

161

29

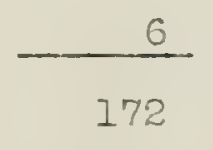

632

4,900

5,231

844

1,985

6.15 

7. Comparison of Illinois River counties: The number of clubs in several caterories based nn number of ducirs killed per club is Given in table 4.

Table 4.-Classification of duck clubs in the Illinois Valley, based on the reported duck kill, 1938.

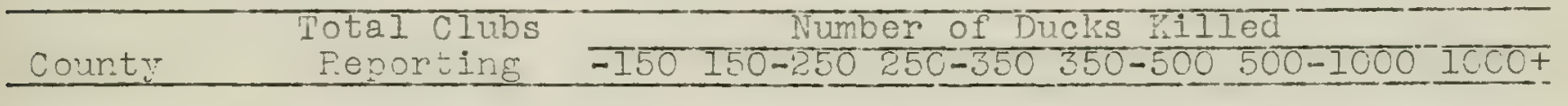

Upper River

Grundy

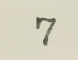

20

La Salie

Bureau

19

19

Putnam

MarshaII

33

13

Peoria

Woodford

Middle River

TazeweII

Fulton

Nas on

Schuyler

Cass

\section{Lover River}

Brown

Morgan

scott

Pike

Jersey

Calhoun

Total

6

13

46

9

33

8

3

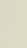

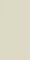



8. Sox ratios: A normal sex ratio is one in which the number of males and ficmales is approximately equal. Species which are monogamous must have a normal sex ratio if they are to produce offspring with greatest efficiency. Wild ducks are believed to be monogamous. The sex ratio in most species of ducks is known to be more or less unbalanced jn favor of the male. While the effects of an abnormal sex ratio are unknown, it is logical to assume that such a condition is unhealthful to the species.

To manage waterfow I successfully, we must learn (1) the sex ratio in tho various waterforl species and (2), if this ratio is abnormal, how the condition can be corrected.

in table 5 .

Our 1938 findings in one species, the mallard, aro given

Table 5.--Sex ratio in mallards, Illinois Valley, 1938.

\begin{tabular}{|c|c|c|c|}
\hline \multirow[b]{2}{*}{ Period } & \multicolumn{2}{|c|}{ Number Inspected } & \multirow{2}{*}{$\begin{array}{c}\text { Per Cent } \\
\text { Drakes }\end{array}$} \\
\hline & Drakes & Hons & \\
\hline Octobor 15-31 & 77 & 82 & 48 \\
\hline November $1-15$ & 68 & 69 & 50 \\
\hline Novcmbor $16-28$ & 196 & 118 & 62 \\
\hline Total & 341 & 269 & 56 \\
\hline
\end{tabular}

Lot us suppose that it is desirable to corrcet the sex ratio in mallards. It will bo noted in table 5 that thero was an excess of hens over drakes early in the scason and that the opposite was true late in the season. Perhaps a later hunting season would tend to discriminate against males, thereby helping to balance the sex ratio.

9. Weights: The bolief has sometimes been exprossed that, since the cessation of logal baiting, ducks passing through IIIinois are in danger of starvation. Vie cxamined over 2,000 ducks in 1938 and found that only duclss with shot wounds showcd signs of starvation. Most of the lightweight ducks werc found to bo late-hatched juveniles. Thoir lack of woight could not be attributed to scarcity of food; they wore merely light-framod individuals. A summary of mallard weights taken in 1938 is given in tablo 6 . 

Table 6.--Woichts of mallards taken in the IlIinois Valley,

\begin{tabular}{|c|c|c|c|c|}
\hline Eeriod & $\begin{array}{l}\text { Wuber } \\
\text { Drakes }\end{array}$ & $\frac{\text { intea }}{\text { Hens }}$ & $\begin{array}{l}\text { Average } \\
\text { Dralies }\end{array}$ & $\frac{\text { veichts }}{\text { Hens }}$ \\
\hline October 15-31 & 77 & 82 & 43.8 & 36.8 \\
\hline November $1-15$ & 68 & 69 & 41.9 & 37.2 \\
\hline November $16-28$ & 196 & 118 & 42.7 & 37.7 \\
\hline Total & 341 & 269 & 42.8 & 37.2 \\
\hline
\end{tabular}

weights in ounces

The fact that the weights of females increased as the season advanced whereas those of the males behaved erratically seems to be further evidence that the male migration is more or less independent of that of the female.

10. Age Eroups: The goal of game management is the ethical harvesting of tho surplus. A surplus in that part of a population in excess of a breedine stock large enough to maintain the species at somo dosired population level. In waterfowl at the present time, thore is no surplus, becauso the desired population level is not in sight. We are, thereforo, harvesting a portion of the capital stock. Although this is not good management, under the circumstances, it is the bost thing to do. It means, however, that unusual vigilance must be directod toward the status of the capital stock, to guard against sharp doflation.

Since increases or decroases in the duck population are primarily the result of successes or failures in breeding, it soems logical that actual measures--not guesswork--are nocessary in determining the number of joung ducks raised. Two methods of measurine the number of young birds in relation to the number of old birds scem to hold the best possibilities: (I) inspection of the kill of hunters (2) banding. Eoth mcthods are jimited in application because of a dearth of definite and usable criteria in some species for separating birds of the year from their parents. Worle is now in progress to romove this obstacle.

\section{ACTIVITIES AND FIIDINGS}

In addition to vood duck nosting studios (to be reported in another papor) the 1339 waterfowl program of the Illinois Natural History Survey has given major considcration, up to septomber 20, to a duck food survey of the Illinois Valloy. This is a continuation of studies started in 1938. 



\section{Aquatic Vogetation Mapping}

Durins both 1938 and 1930 maps have been made to scale showine the aquatic plants found in the bottom-land lakes of the Illinois yalley. These maps indicate the water depth and turbidity when the survey was made. A follow-up of the mapping is the collection dumine the hunting season of stomachs from duciss shot over the lakes previously mapped. The resulting information gives a picture of what plants are chosen as food by ducks, and what the relative akundance anc distribution of these food plants is throughout the valley. Also learned is the area occupied by plants which do not produce duck foods. An accumulation of this information, auEmented bit special studies, should eventually yield a plan for reducing the area of non-food plants by increasing the area of food plants.

and 1939 follows.

In 1938 high wator vas provalent throughout the valley until the latter part of July. A drouth then resulted in an abnormally low water stage throwgliout the rumainder of the erowing season for plants. The high water until midsummor precluded the growth of such important ducli food plants as nut grass (Cyperus), duck milict (Ichinochloa), sav Erass (Lucsia), a numbcr ol smartweds (Polygonum) and pícweud (Acnida) from erowing on the mud flats. Likewise, becouse of the fluctuating wattr lovels and high turbidity, fow important aquatic plants upon which ducks focd were ablo to thrivo in tho parts of the lalres which did not go dry. The two most abundant plants in the bottom-land lakes of Illinois, Amorican lotus (Nolumbo lutca) and the river bulrush (Scirous fluviatilis) arc ro lativoly unimortant as duck food producers.

Tlus, during tho hunting season of 1938, there was a scarcity of natural ducl foods in most of the lakes, and the water level vas so low as to make many lakes voritable mud flats. Such onvironmental conditions lud the ducks to concentrate in aroas possessing a bountiful supply of natural food, and to rest in tho contor of large lakes during the day, procuring their food from cornficlds during the cvening and morning hours.

A new factor entercd the picture in 1939. Two wicket type dams--one at Whitchousc, near Pelin, the other at La Grange, below Ecardstown-woro placcd in opcration to compensate for tho Iow wator stage brought about by roducing tho diversion from Lake Michigan. The lihitchouse dam raiscd the wator in the Illinois Rivor and adjoining lakcs from Pokin to Honnepin; tho Ia Grango dam raised the water lovol as far as Erowing and the Sangamon Rivor. Botwocn Pokin and Erowning the lowest stago in the rocent history of the Illinois Fivor provailed during nugust and soptembor of 1939. Fomer larece lakes, such as Cloar, quivor and crano, became Iittle moro than pudalcs. 

In the following paragraphs is given a summary of the water and duck food conditions found at some of the lakes stmdied during 1938 and 1939 .

several. ears afo at Starvoi tock, has a fa irly constant water level througioit the Tsar. Corsequentle, tho vegutation is more luxuriant and better stabilized than in other Illinois bottom-land lakes in which wator levels fluctuate greatly. Eeds of sago (Potamogeton pectinatus) and long-lcaved nondwetd (Potamogeton americanus) occir up to deptis of $t$ feut. Lhure are two areus covered witha scattcring growth of wild celery (Valisneria), one of the few places in the Illinois valley where it occurs. Coontail (Ceratophyllum), ductr potato (Sagitaria) and duckweeds are other aburarat specics.

Depue and Spijing Lake, Depue.--A paucity of duck food plants prevailed In both 13, and 1939 . No chance in status of ducl food olants and water livels ocounred in 1939, becauso these lakes are too far north of the new Whiteliouse Dam to benefit from its effects. Large beds of river bulrush occurred about both lales. Small patches of marsh smartwaid (Polyconim nuhlonborgii) wore prosent but those produced little seedin $19 \overline{39}$.

Goose Pona, Pntnam.--This lalve containoa in 1939 very extensive beds of the unimpotant duck food plant, rivor bulrush. Toxt in abundance was the Amorican lotus, which is reported to have increased in arca durine $193 \mathrm{~s}$. Trigu beas of dic? potato (Sacittaria lotifolia) maintaind thoir size ceginst uncroacimint bu river burris. Scattored plants of saco pondwed wore founc in the oper witer of tilo lake and in a number of wooded potholes. Stands of giant bur roed (Sparganium evrycarpum) also occurred.

Sawmil Lake, wermy.-The dicle food nlants, scarci in $19 z 8$,

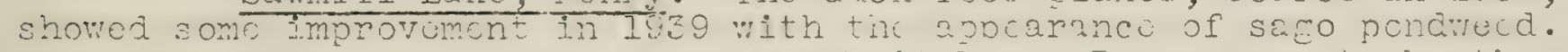
A higher wator level, duc to the ncw Whitchouse Dam, scems to be the cause. Extonsive boas of rivor bulrush and American lotus occurred in both 1938 and 1939. A slight decreasc in lotus was noted in 1939.

Goose Inke, Sparland.--This state public shooting ground had 2 higher weter level, due to the vikitehous Dam, and but ter duck food conditions in 1939 than in 1938. Scattcred beds of marsh smartweed, an irmportant ducle food plant, occurred ahout the lake in 1930 . Pnots of the river ridge were covered with luxuriant grov:ths of nodding smartwoed (Polygonum laprthifolinu), duck millet, saw erass und pigweed.

Douglass Ialce Drainage District, Chiliicothe--About twothirds of this uris wai covured in l938 anc lajo UT river bulmisil. Marsh smartwecd, quito abundant in 1938, was reduced in aroa in 1939. Tumerous patches of wilto water lily ( 

coontail (Ccratopkyllur:) vecurred woth wase in tou Penci ora othor ponds in the river bulrusis march. iio vild rice (zizunis) wis found in 1938; yet in 1939 fair stands appoarod sround $\overline{\mathrm{K}} \overline{\mathrm{ice}}$ Pond and two othor ponds. Sago pondwec d w.s much mone oomon in 1839 tiur in 1830.

Eig Lake and Goose Pond, -rmen.-.Eig Iake contained extensive American lotus a nu river burviti beds. In 1038 marsh smartweed was abundant about the lalre, wht in 7.23 most nf the sirartweed vas replaced by river bulrush. Two small patches of wild rice appeared in 1939.

In 1938, Goose Pond had the largest bed of duck potato in the Illinois vallej. Eecause of high water durire the crowing seasor of 1938 anc 1930 , resulting in subremeroe of tie plarts, this sposies was larcely replaced in 1039 by hmorican lotus and coontail. jatehos of white water lily were materially reduced in size in 1939.

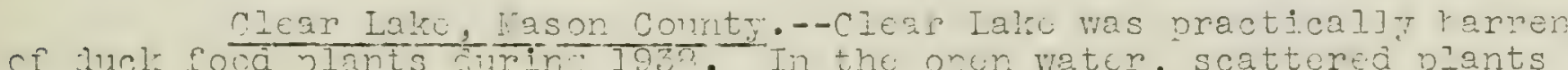

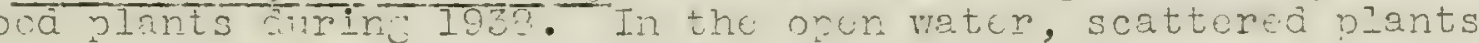
of sago and long-leaved pondwed occurred, while alone the shore a fow bods of spilco rush (Eleocharis), river bulrush and duck potato wore found. Druine the summer of 1839 the wator of this le le recead to such an cxtont that most of the lake was a mid flat. These drouth conditions were clue to the fact that the pool of the La Grange Dam did not cxtend far onouch upstream, and the flow tirrough the valiey was Icss than in previous years.

On this exicnsivo mua flat such valuable duck food plants as

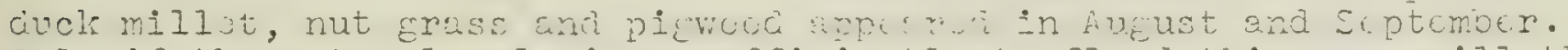
Only if the water level risos sufficiontly to flood this aroa will tho cxcellent food become available to watorfonl.

Andorson Iake, Astoria.--In this lake, there was very little

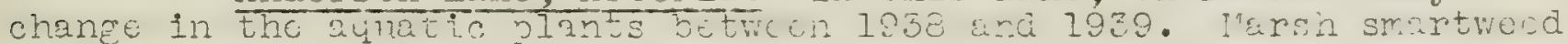
was the most abundint soocies, Amorican lotus second and coontail third.

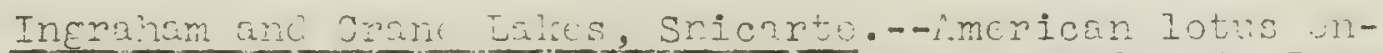

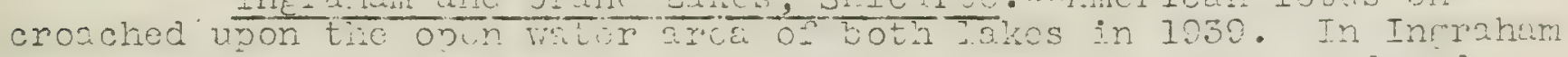
Lake, lotus covered about 85 per cont of tho area. Sago pondweod and long-lcaved pondwecd, scarce in Crane Iake in 1938, were almost wanting in 1839 .

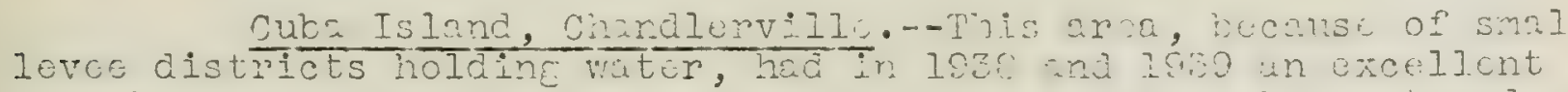
crowth of good duck food plants. In both yoars marsh smartwoed was tho most abundant of those food species. In 1832 it was somowhat lcss abundant than in 1938. Saw grass Was sceond in abundance and covered an cqual arca in hoth yecrs. Amorican lotus increased slightly in 1939 over 1938. 


Teblo 7.--Plants most often ropresented in 285 mallard stomachs, Illinois Valloy, 1838.

\begin{tabular}{|c|c|c|c|}
\hline Pl:rit & $\mathrm{V} \cap \operatorname{lumo*}$ & Pon & Cont前米 \\
\hline Corn (zea indenta) & $452 \cdot 7$ & & 40 \\
\hline Saw grass (Jeersia oryzoides) & 138.6 & & 13 \\
\hline Smartweed (Polygonum Muhlenbergii) & 61.6 & & 6 \\
\hline Nut grass (Cyperus esculentus) & 42.5 & & 4 \\
\hline Coontail (Ceratophyllum dem & $31 \cdot 2$ & & 3 \\
\hline Pondweed (Potamogeton anericanus) & 11.8 & & 1 \\
\hline
\end{tabular}

*Volume expressed in cubic centimeters. of plant food.

* Based on a total volume of $1,107.5$ cubic centimeters

Pintail.- Nineteen plant and 11 animal species were identified from 6z pintail stonichs. The fivo most important of these aro listed in table 8 with comparative ratings.

Table 8.--Plants most often represented in 62 pintail stomaclis, Illinois Valley, 1938.

\begin{tabular}{lcc}
\hline Plant & Volume* Per cent** \\
\hline Corn (Zea indenta) & 132.8 & 56 \\
Nut grass (Eyperus esculentus) & 20.1 & 8 \\
Buckbrush (Cephalanthus) & 12.9 & 6 \\
Saw grass (Leorsia oryzoides) & 7.4 & 3 \\
Spike rush (Eloocharis) & 3.6 & 2 \\
\hline
\end{tabular}

*Volume in cubic centimetors. plant food.

**Eased on a total volume of 234.5 cubic centimeters of

Animal foods were relatively unimportant in mallards and pintails killed durine, the period November 6-27. 

Lesser Scaup (Eluebill).-.rearly 95 per cent of the con-

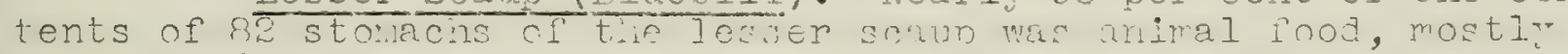
molluscs (Amnicola, Sphaerium, Pisidium). Coontail and duck potato

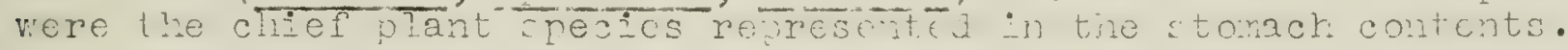

Iirc-nedrod Inol: (Elaskjacls).--plont food was somewhat rrefurred to animal food ky thes ditine cuck, as represented hy thu 4 stomachs examincd. Sago and long-leaved pondweed seods made up the bulk of the contents. Of the animal foods, molluscs and midgo larvae composod 90 per cent of the volume.

Summary of Stomach inalysis.--over 100 plant anj animul specics hre been identifjed fror the duar stonch contents so far oxamined. Iess than a fifth of these foods, however, constitute an important part of the diet. Corn wasted during the harvest is utilizod heavily by mallards and pintails which, together, make up the major part of the duck flight through Illinois. So long as agricultural practicos borderine the IIlinnis River remain the same as thoy aro today thore is little chance for widosproad starvation among ducles during the hunting scason, cvor if the supply of natural food fails. The boliof somotimes cxprossod, that baiting is nocessary to prevont duck storvation, docs not apply to Illinois conditions.

Thoro is some ovidonco that ducirs rosort to cornfiold feedIng through nocossity rather than preforenco. The stomach contents of the ducks killed where cxcollcnt naturs l food conditions prevailod containcd comparativoly littlo corn.

Stomach analysos, as woll cs f: $7 d$ ojscrvations, indicato that tho thousands of dollars spont in tic past by ducle clubs in planting wild colory, wild rico, wapito anc sago have accomplishod littlo in bottoring tho notural food conditions of the Illinois valloy. Studies proposod for the futuro should evolve a planting schodule suitod to tiro oyacting roquirements of the Illinois piver arca. 




